\title{
Penggunaan Mikoriza Arbuskular dalam Pertumbuhan Bibit Anakan Salak Sidimpuan (Salacca sumatrana Becc.)
}

\section{The Usage of Arbuscular Mycorrhiza on the Growth of Salak Sidimpuan (Salacca sumatrana Becc.) Seedling}

\section{Rizky Amnah dan Meiliana Friska}

Program Studi Agroekoteknologi, Fakultas Pertanian, UGN, Padangsidimpuan

*Corresponding author: amnahi@yahoo.com

\begin{abstract}
Salak Sidimpuan (Salacca sumatrana Becc.) is a plant that has shallow roots that limits the ability of roots to absorb nutrients. One of the efforts that could be done to increase shoots growth is through arbuscular mycorrhiza application. This study aims to see the effect of the use of arbuscular mycorrhiza in the growth of salak Sidimpuan seedlings. This research was done at screen house of Agriculture Faculty, University of Graha Nusantara Padangsidimpuan. The experiment design was arranged in factorial randomized block design, two factors with three replications: first factor was arbuscular mycorrhiza: $M_{1}$ (Glomus sp) dan $M_{2}$ (Acaulospora sp). Second factor was arbuscular mycorrhiza dosage: $D_{0}$ (control), $D_{1}$ (50g MA/polybag), $D_{2}$ (100g MA/polybag) dan $D_{3}$ (150g MA/polybag). Results of the experiment showed that there was an interaction between the type and dose of arbuscular mycorrhiza to the average height increase of salak Sidimpuan seedlings with the best treatment in $M_{2} D_{3}$ (Acaulospora sp dan $150 \mathrm{~g} M A$ polybag) and the average number of leaves of salak Sidimpuan seedlings with the best treatment in $M_{1} D_{3}$ (Glomus sp dan $150 \mathrm{~g}$ MA/polibag).
\end{abstract}

Keywords: Shoot, Salak Sidimpuan, Growth, Seedling

\begin{abstract}
ABSTRAK
Salak Sidimpuan (Salacca sumatrana Becc.) merupakan tanaman yang memiliki perakaran yang dangkal sehingga membatasi kemampuan akar menyerap unsur hara. Salah satu cara yang dapat dilakukan untuk meningkatkan pertumbuhan bibit anakan salak Sidimpuan yaitu melalui penggunaan mikoriza arbuskular (MA). Penelitian ini bertujuan untuk melihat pengaruh penggunaan Mikoriza arbuskular dalam pertumbuhan bibit anakan salak Sidimpuan. Penelitian ini dilaksanakan di Rumah Kasa Fakultas Pertanian Universitas Graha Nusantara Padangsidimpuan. Rancangan yang digunakan adalah Rancangan Acak Kelompok Faktorial dengan dua faktor dan 3 ulangan. Faktor pertama ( 2 taraf jenis MA) yaitu: $\mathrm{M}_{1}$ (Glomus sp) dan $\mathrm{M}_{2}$ (Acaulospora sp). Faktor kedua (4 taraf dosis MA), yaitu $\mathrm{D}_{0}$ (Kontrol), $\mathrm{D}_{1}$ (50g MA/polibag), $\mathrm{D}_{2}$ (100g MA/polibag) dan $\mathrm{D}_{3}$ (150g MA/polibag). Hasil penelitian menunjukkan bahwa terdapat interaksi antara jenis dan dosis Mikoriza arbuskular terhadap rata-rata pertambahan tinggi bibit anakan salak Sidimpuan dengan perlakuan terbaik pada $\mathrm{M}_{2} \mathrm{D}_{3}$ (Acaulospora sp dan $150 \mathrm{~g} \mathrm{MA} /$ polibag) dan rata-rata pertambahan jumlah daun bibit anakan salak Sidimpuan dengan perlakuan terbaik pada $\mathrm{M}_{1} \mathrm{D}_{3}$ (Glomus $s p$ dan $150 \mathrm{~g}$ MA/polibag)
\end{abstract}

Kata kunci: Anakan, Salak Sidimpuan, Pertumbuhan, Bibit 


\section{PENDAHULUAN}

Salak Sidimpuan merupakan komoditi unggul lokal di Kabupaten Tapanuli Selatan dengan sentra produksi di kecamatan Angkola Barat, Angkola Timur dan Angkola Selatan. Luas penanamannya mencapai 13.928 Ha. Salak Sidimpuan sangat potensial untuk dikembangkan, namun dalam pengembangannya diperlukan penyediaan bibit dengan mutu baik.

Tanaman salak berakar serabut yang menjalar mendatar di bawah permukaan tanah, letak perakarannya dangkal, penyebarannya tidak luas sehingga cepat terpengaruh bila terjadi kekeringan serta mudah roboh bila diterpa angin kencang (Anarsis, 2006). Letak perakarannya yang dangkal ini juga menyebabkan tanaman salak terbatas dalam penyerapan unsur hara dan air. Sistem perakaran yang baik akan menyokong pertumbuhan tanaman yang baik pula. Dalam kegiatan pembibitan tanaman salak, perlu dilakukan suatu teknologi yang dapat membatu meningkatkan pertumbuhan tanaman. Salah satunya yaitu penggunan Mikoriza arbuskular.

Mikoriza arbuskular merupakan pupuk hayati yang dapat diaplikasikan guna meningkatkan pertumbuhan tanaman tidak terkecuali tanaman salak. Pada lingkungan alami, hampir $80 \%$ akar tanaman membentuk asosiasi mikoriza, yaitu: graminae, leguminosa, solanaceae, liliaceae, compoceae, tanaman pertanian dan hortikultura (Hanafiah et al. 2009), tanaman pangan, perkebunan, kehutanan, maupun tanaman penghijauan (Kilham, 1994). Mikoriza berperan penting dalam meningkatkan pertumbuhan tanaman agrikultur, holtikultura, dan tanaman hutan (Wubet et al. 2003).

Tanaman yang diinfeksi dengan Mikoriza arbuskular menunjukkan pertumbuhan yang lebih tinggi jika dibandingkan dengan tanaman yang tidak terinfeksi (Sinwin et al. 2007). Sedangkan hasil penelitian Daras et al. (2013) diperoleh bahwa penggunaan mikoriza meningkatkan bobot kering akar kopi dan tingkat infeksi mikoriza yang relatif cukup besar $(31,46 \%)$ diikuti oleh perbaikan komponen pertumbuhan tanaman (tinggi tanaman, diameter batang, dan bobot kering daun). Hal ini terjadi karena Mikoriza arbuskular mampu meningkatkan penyerapan unsur hara dan air akar tanaman.

Dalam

meningkatkan pengembangan budidaya salak Sidimpuan di Kabupaten Tapanuli Selatan, peneliti tertarik untuk mengkaji penggunaan Mikoriza Arbuskular dalam pertumbuhan bibit anakan salak Sidimpuan (Salacca sumatrana Becc.) di rumah kasa.

\section{BAHAN DAN METODE}

Penelitian ini dilaksanakan di rumah kasa Fakultas Pertanian, Universitas Graha Nusantara Padangsidimpuan. Penelitian ini menggunakan bahan-bahan meliputi: bibit anakan salak Sidimpuan berumur 3 bulan sehat dan seragam, Mikoriza arbuskular (Glomus sp dan Acaulospora sp), top soil, batuan fosfat dan NPK. Peralatan yang digunakan antara lain polibag, meteran, timbangan, terpal, dan sprayer.

Penelitian

menggunakan

Rancangan Acak Kelompok (RAK) Faktorial dengan 2 faktor perlakuan dengan 3 ulangan. Faktor pertama terdiri dari 2 taraf jenis MA yaitu: $\mathrm{M}_{1}$ (Glomus sp) dan $\mathrm{M}_{2}$ (Acaulospora $\mathrm{sp}$ ). Faktor kedua terdiri dari 4 taraf dosis MA, yaitu $\mathrm{D}_{0}$ (Kontrol), $\mathrm{D}_{1} \quad(50 \mathrm{~g} \quad \mathrm{MA} / \mathrm{polibag}), \quad \mathrm{D}_{2} \quad(100 \mathrm{~g}$ MA/polibag) dan $\mathrm{D}_{3}$ (150g MA/polibag).

Media tanam yang digunakan yaitu tanah kering udara yang dimasukkan ke dalam polibag dengan berat tanah $5 \mathrm{~kg}$ setara berat kering mutlak. Bibit anakan salak ditanamkan dengan jumlah satu anakan per polibag. MA diinokulasikan pada saat pindah tanam bibit anakan salak ke dalam polibag. Aplikasi Mikoriza arbuskular 
dilakukan dengan menginokulasikan inokulum MA (campuran spora, hifa, akar terinfeksi dan tanah) di sekitar akar bibit tanaman untuk memudahkan proses infeksi akar. MA diaplikasikan sesuai dengan perlakuan. Tanaman dipupuk dengan batuan fosfat pada umur satu minggu setelah tanam sebanyak 25g/polibag. Sedangkan pupuk NPK (majemuk) diberikan pada umur empat minggu setelah tanam sebanyak 7 g/polibag. Pupuk

\section{HASIL DAN PEMBAHASAN}

\section{Rata-rata Pertambahan Tinggi (cm) Bibit Anakan Salak Sidimpuan}

Pertambahan tinggi bibit anakan salak Sidimpuan diukur setiap bulannya sejak pindah tanam hingga berumur tiga bulan setelah pindah tanam. Faktor jenis Mikoriza diaplikasikan dengan cara membuat alur pupuk di sekeliling tanaman. Bibit anakan salak ditumbuhkan di rumah kasa dan disiram setiap hari pada sore hari hingga kapasitas lapang.

Data pengamatan dianalisis dengan ANOVA dan dilanjutkan dengan uji beda rata-rata berdasarkan Uji Jarak Berganda Duncan (DMRT) pada taraf 5\% bila dalam uji F memperlihatkan pengaruh yang nyata.

arbuskular berpengaruh nyata terhadap pertambahan tinggi bibit anakan salak Sidimpuan pada umur 1, 2 dan 3 bulan setelah pindah tanam (BSPT) dengan perlakuan terbaik terdapat pada jenis Mikoriza arbuskular Acauslospora sp ( $\left.\mathrm{M}_{2}\right)$. Acauslospora sp lebih meningkatkan pertambahan tinggi bibit anakan salak Sidimpuan dibandingkan Glomus sp $\left(\mathrm{M}_{1}\right)$.

Tabel 1. Rata-rata pertambahan tinggi (cm) bibit anakan salak Sidimpuan pada umur 1, 2 dan 3 bulan setelah pindah tanam (BSPT) akibat pemberian jenis dan dosis Mikoriza arbuskular serta interaksinya.

\begin{tabular}{|c|c|c|c|}
\hline \multirow[t]{2}{*}{ Dosis Mikoriza arbuskular } & \multicolumn{2}{|c|}{ Mikoriza Arbuskular } & \multirow[t]{2}{*}{ Rataan } \\
\hline & $\mathrm{M}_{1}$ & $\mathrm{M}_{2}$ & \\
\hline $1 \mathrm{BSPT}$ & \multicolumn{2}{|c|}{-------- cm -------- } & \\
\hline $\mathrm{D}_{0}$ & $0.93 \mathrm{~b}$ & $0.90 \mathrm{~b}$ & $0.92 \mathrm{~b}$ \\
\hline $\mathrm{D}_{1}$ & $1.23 \mathrm{~b}$ & $3.80 \mathrm{a}$ & $2.52 \mathrm{a}$ \\
\hline $\mathrm{D}_{2}$ & $1.60 \mathrm{ab}$ & $2.53 \mathrm{ab}$ & $2.07 \mathrm{ab}$ \\
\hline $\mathrm{D}_{3}$ & $1.77 \mathrm{ab}$ & $3.70 \mathrm{a}$ & $2.73 \mathrm{a}$ \\
\hline Rataan & $1.38 \mathrm{~b}$ & $2.73 \mathrm{a}$ & \\
\hline $2 \mathrm{BSPT}$ & \multicolumn{2}{|c|}{-------- cm -------- } & \\
\hline $\mathrm{D}_{0}$ & $2.77 \mathrm{c}$ & $2.27 \mathrm{c}$ & $2.52 \mathrm{~b}$ \\
\hline $\mathrm{D}_{1}$ & $4.47 b c$ & $6.70 \mathrm{ab}$ & $5.58 \mathrm{a}$ \\
\hline $\mathrm{D}_{2}$ & $4.97 b c$ & $6.03 \mathrm{ab}$ & $5.50 \mathrm{a}$ \\
\hline $\mathrm{D}_{3}$ & $4.73 b c$ & $8.03 \mathrm{a}$ & $6.38 \mathrm{a}$ \\
\hline Rataan & $4.23 \mathrm{~b}$ & $5.76 \mathrm{a}$ & \\
\hline $3 \mathrm{BSPT}$ & \multicolumn{2}{|c|}{-------- cm -------- } & \\
\hline $\mathrm{D}_{0}$ & $4.13 \mathrm{c}$ & $3.77 \mathrm{c}$ & $3.95 \mathrm{~b}$ \\
\hline $\mathrm{D}_{1}$ & $6.80 \mathrm{~b}$ & $8.77 \mathrm{ab}$ & $7.78 \mathrm{a}$ \\
\hline $\mathrm{D}_{2}$ & $7.40 \mathrm{~b}$ & $8.37 \mathrm{ab}$ & $7.88 \mathrm{a}$ \\
\hline $\mathrm{D}_{3}$ & $7.13 \mathrm{~b}$ & $10.47 \mathrm{a}$ & $8.80 \mathrm{a}$ \\
\hline Rataan & $6.37 \mathrm{~b}$ & $7.84 \mathrm{a}$ & \\
\hline
\end{tabular}

Keterangan: Angka yang diikuti oleh huruf yang berbeda pada kolom dan baris yang sama menunjukkan perbedaan nyata pada taraf 5\% menurut uji DMRT 
Faktor dosis Mikoriza arbuskular berpengaruh nyata terhadap pertambahan tinggi bibit anakan salak Sidimpuan pada umur 1, 2 dan 3 BSPT. Terdapat kecenderungan pertambahan tinggi bibit anakan salak dengan semakin tingginya dosis Mikoriza arbuskular yang diberikan. Pertambahan tinggi bibit anakan terendah terdapat pada perlakuan $\mathrm{D}_{0}$ (kontrol) yaitu sebesar 0,92 cm (1 BSPT), 2,52 cm (2 BSPT) dan 3,95 (3 BSPT). Perlakuan $\mathrm{D}_{0}$ (kontrol) berbeda nyata dengan perlakuan $\mathrm{D}_{1}(50 \mathrm{~g}$ MA/polibag), $\mathrm{D}_{2}$ (100g MA/polibag) dan $\mathrm{D}_{3}$ (150g MA/polibag) dalam meningkatkan pertambahan tinggi bibit anakan salak. Perlakuan terbaik yaitu pada perlakuan $\mathrm{D}_{3}$ (150g MA/polibag) walaupun perlakuan $\mathrm{D}_{3}$ berbeda tidak nyata dengan perlakuan $\mathrm{D}_{1}$ dan $\mathrm{D}_{2}$.

Selain itu, pada Tabel 1 di atas juga dapat dilihat bahwa interaksi penggunaan jenis dan dosis Mikoriza arbuskular berpengaruh nyata terhadap pertambahan tinggi bibit anakan salak pada umur 1, 2 dan 3 BSPT. Kombinasi perlakuan $\mathrm{M}_{2} \mathrm{D}_{0}$ memberikan pertambahan tinggi bibit anakan salak terendah namun berbeda tidak nyata dengan pelakuan $\mathrm{M}_{1} \mathrm{D}_{0}$. Kombinasi perlakuan $\mathrm{M}_{2} \mathrm{D}_{3}$ berbeda tidak nyata dengan kombinasi perlakuan $\mathrm{M}_{2} \mathrm{D}_{1}$ dan $\mathrm{M}_{2} \mathrm{D}_{2}$ serta berbeda nyata dengan perlakuan yang lainnya pada umur 2 dan 3 BSPT. Namun pertambahan tinggi bibit anakan salak tertinggi terdapat pada kombinasi perlakuan $\mathrm{M}_{2} \mathrm{D}_{3}$ (Acauslospora $\mathrm{sp}$ dan $150 \mathrm{~g}$ MA/polibag), yaitu sebesar $8,03 \mathrm{~cm}$ (2 BSPT) dan 10,47 (3 BSPT).

Secara alami, akar tanaman dapat diinfeksi oleh MA. Pemberian inokulum MA memberikan peluang yang besar akar tanaman terinfeksi. Semakin banyak dosis MA yang diberikan maka kemungkinan akar terinfeksi semakin besar pula. Hal ini sejalan dengan hasil penelitian dimana kombinasi perlakuan $\mathrm{M}_{2} \mathrm{D}_{3}$ (Acauslospora sp dan $150 \mathrm{~g}$ $\mathrm{MA} /$ polibag) memberikan pertambahan tinggi bibit anakan salak tertinggi. Infeksi ini akar oleh MA tentunya dipengaruhi oleh beberapa faktor, yaitu: jenis cendawan dan lingkungan seperti $\mathrm{pH}$, temperatur, kelembaban, pestisida dan kandungan unsur hara Tingginya kadar inokulum dalam tanah dapat meningkatkan derajat infeksi akar sampai titik optimum tertentu (Wood, 1995).

Akar tanaman yang terinfeksi oleh MA, memberikan beberapa manfaat bagi pertumbuhan tanaman maupun bagi MA sendiri. Hubungan MA dengan tanaman inangnya adalah saling menguntungkan. MA memperoleh karbohidrat (sukrosa, glukosa dan fruktosa) dari tanaman inang (Smith dan Read, 2008) sedangkan tanaman inang memperoleh suplai unsur hara dari MA (Andrade et al. 2009). Pemberian mikoriza dan frekuensi pemberian air memberikan pengaruh nyata terhadap tinggi bibit, diameter batang, berat kering pupus, berat kering akar, luas daun dan persentase infeksi mikoriza (Neliyati , 2010

\section{Rata-rata Pertambahan Jumlah Daun (helai) Bibit Anakan Salak Sidimpuan}

Pengamatan jumlah daun bibit anakan salak Sidimpuan dilakukan dengan menghitung jumlah daun yang telah terbuka sempurna pada umur 3 BSPT. Berdasarkan Tabel 2 dapat dilihat bahwa faktor jenis Mikoriza arbuskular tidak berpengaruh nyata terhadap pertambahan jumlah daun bibit anakan salak Sidimpuan. Jenis Mikoriza arbuskular Glomus sp $\left(\mathrm{M}_{1}\right)$ lebih meningkatkan pertambahan jumlah daun bibit anakan salak Sidimpuan dibandingkan Acauslospora sp $\left(\mathrm{M}_{2}\right)$.

Faktor dosis Mikoriza arbuskular berpengaruh nyata terhadap pertambahan jumlah daun bibit anakan salak Sidimpuan. Terdapat kecenderungan pertambahan jumlah daun bibit anakan salak dengan semakin tingginya dosis Mikoriza arbuskular yang diberikan. Pertambahan jumlah daun bibit anakan terendah terdapat pada perlakuan $\mathrm{D}_{1}$ (50g MA/polibag) yaitu sebesar 0,67 helai. Sedangkan perlakuan $\mathrm{D}_{3}$ (150g MA/polibag) berbeda tidak nyata dengan perlakuan $\mathrm{D}_{0}$ (kontrol) dan $\mathrm{D}_{2}$. 
Tabel 2. Rata-rata pertambahan jumlah daun (helai) bibit anakan salak Sidimpuan pada umur 3 bulan setelah pindah tanam (BSPT) akibat pemberian jenis dan dosis Mikoriza arbuskular serta interaksinya.

\begin{tabular}{cccc}
\hline \multirow{2}{*}{ Dosis Mikoriza arbuskular } & \multicolumn{2}{c}{ Mikoriza Arbuskular } & \multirow{2}{*}{ Rataan } \\
\cline { 2 - 3 } & $\mathrm{M}_{1}$ & $\mathrm{M}_{2}$ & \\
\hline & ------- helai ------- & $1.17 \mathrm{ab}$ \\
$\mathrm{D}_{0}$ & $1.00 \mathrm{ab}$ & $1.33 \mathrm{a}$ & $0.67 \mathrm{~b}$ \\
$\mathrm{D}_{1}$ & $0.67 \mathrm{~b}$ & $0.67 \mathrm{~b}$ & $1.17 \mathrm{ab}$ \\
$\mathrm{D}_{2}$ & $1.33 \mathrm{ab}$ & $1.00 \mathrm{ab}$ & $1.50 \mathrm{a}$ \\
$\mathrm{D}_{3}$ & $2.00 \mathrm{a}$ & $1.00 \mathrm{ab}$ & \\
\hline Rataan & 1.25 & 1.00 & \\
\hline
\end{tabular}

Keterangan:Angka yang diikuti oleh huruf yang berbeda pada kolom dan baris yang sama menunjukkan perbedaan nyata pada taraf $5 \%$ menurut uji DMRT

Terdapat interaksi penggunaan jenis dan dosis Mikoriza arbuskular terhadap pertambahan jumlah daun bibit anakan salak. Kombinasi perlakuan $\mathrm{M}_{1} \mathrm{D}_{1}$ dan $\mathrm{M}_{2} \mathrm{D}_{1}$ memberikan pertambahan jumlah daun bibit anakan salak terendah yaitu sebesar 0,67 helai. Sedangkan kombinasi perlakuan $\mathrm{M}_{1} \mathrm{D}_{3}$ memberikan pertambahan jumlah daun bibit anakan salak tertinggi sebesar 2,00 helai walaupun berbeda tidak nyata dengan kombinasi perlakuan lainnya selain $\mathrm{M}_{1} \mathrm{D}_{1}$ dan $\mathrm{M}_{2} \mathrm{D}_{1}$.

Secara alami, dalam mendukung pertumbuhan tanaman khususnya dipembibitan MA memiliki beberapa peran antara lain: meningkatkan ketersediaan unsur hara bagi tanaman, ketahanan terhadap penyakit (Borowicz, 2001),

Berdasarkan Tabel 3 dapat dilihat bahwa baik faktor jenis,dan dosis Mikoriza arbuskular maupun interaksinya tidak berpengaruh nyata terhadap pertambahan diameter batang bibit anakan salak Sidimpuan. Kombinasi perlakuan $\mathrm{M}_{2} \mathrm{D}_{2}$ (Acauslospora sp dan 100g MA/polibag) memberikan pertambahan dimeter batang tertinggi jika dibandingkan jika dibandingkan dengan perlakuan lainnya.

Dosis MA mampu meningkatkan pertambahan diameter batang bibit anakan salak meskipun tidak berpengaruh secara nyata. Hal ini karena MA yang menginfeksi sistem perakaran tanaman inang perbaikan struktur makro dan mikroagregat tanah (Gamal, 2005), menghasilkan enzim fosfatase yang dapat meningkatkan ketersediaan P (Bolan, 1991), serta mampu meningkatkan penyerapan air bagi tanaman (Hanafiah dkk., 2009). Hodiah (2008) menyatakan bahwa infeksi mikoriza dapat meningkatkan pertumbuhan tanaman termasuk jumlah daun, tinggi tanaman dan luas daun karena tanaman bermikoriza dapat menyerap unsur hara makro dalam jumlah beberapa kali lebih besar dibanding tanpa mikoriza.

\section{Rata-rata Pertambahan Diameter Batang (cm) Bibit Anakan Salak Sidimpuan}

memproduksi jaringan hifa eksternal yang tumbuh secara ekspansif dan menembus lapisan subsoil sehingga meningkatkan kapasitas akar dalam menyerap hara dan air (Cruz et al.2004). 
Tabel 3. Rata-rata pertambahan diameter batang $(\mathrm{cm})$ bibit anakan salak Sidimpuan pada umur 3 bulan setelah pindah tanam (BSPT) akibat pemberian jenis dan dosis Mikoriza arbuskular serta interaksinya.

\begin{tabular}{cccc}
\hline \multirow{2}{*}{ Dosis Mikoriza arbuskular } & \multicolumn{2}{c}{ Mikoriza Arbuskular } & \multirow{2}{*}{ Rataan } \\
\cline { 2 - 3 } & \multicolumn{1}{c}{$\mathrm{M}_{1}$} & $\mathrm{M}_{2}$ & \\
\hline & $-------\mathrm{cm} \mathrm{------}$ & 0.45 \\
$\mathrm{D}_{0}$ & 0.42 & 0.47 & 0.38 \\
$\mathrm{D}_{1}$ & 0.39 & 0.38 & 0.48 \\
$\mathrm{D}_{2}$ & 0.47 & 0.48 & 0.36 \\
$\mathrm{D}_{3}$ & 0.30 & 0.42 & \\
\hline Rataan & 0.40 & 0.44 & \\
\hline
\end{tabular}

Keterangan:Angka yang diikuti oleh huruf yang berbeda pada kolom dan baris yang sama menunjukkan perbedaan nyata pada taraf 5\% menurut uji DMRT

\section{SIMPULAN}

Jenis Mikoriza arbuskular berpengaruh nyata terhadap rata-rata pertambahan tinggi bibit anakan salak Sidimpuan. Perlakuan terbaik pada $\mathrm{M}_{2}$ (Acaulospora $\mathrm{sp}$ ).

Dosis Mikoriza arbuskular berpengaruh nyata terhadap rata-rata pertambahan tinggi dan jumlah daun bibit anakan salak Sidimpuan. Perlakuan terbaik pada $\mathrm{D}_{3}(150 \mathrm{~g}$ MA/polibag).

Terdapat interaksi antara jenis dan dosis Mikoriza arbuskular terhadap rata-rata pertambahan tinggi bibit anakan salak Sidimpuan dengan perlakuan terbaik pada $\mathrm{M}_{2} \mathrm{D}_{3} \quad$ (Acaulospora sp dan $150 \mathrm{~g}$ MA/polibag) dan rata-rata pertambahan jumlah daun bibit anakan salak Sidimpuan dengan perlakuan terbaik pada $\mathrm{M}_{1} \mathrm{D}_{3}$ (Glomus $s p$ dan 150 g MA/polibag)

\section{DAFTAR PUSTAKA}

Anarsis W. 2006. Agribisnis Komoditas Salak. PT. Bumi Aksara. Jakarta

Andrade, S. A. L., P. Mazzaferal, M. A. Schiavinato, and A. P. D. Silveira. 2009. Arbuscularmycorrhizal association in coffee. Journal of AgriculturalScience 147: 105-115.

Bolan, N. S. 1991. A critical review on the role of mycorrhizal fungi in the uptake of phosphorus by plants. Plant Soil 134: 189-207.
Borowicz, V. A. 2001. Do arbuscular mycorrhiza fungi alter plant-pathogen relatios? Ecology 82:3057-3068.

Cruz, C., J.J. Green, C.A. Watson, F. Wilson, dan M.A. Martin-Lucao. 2004. Functional aspect of root architecture and mycorrhizal inoculation with respect to nutrient uptake capacity. Mycorrhiza 14: 177-184.

Daras, U.,O. Trisilawati dan I. Sobari. 2013. . Pengaruh Mikoriza dan Amelioran terhadap Pertumbuhan Benih Kopi. Buletin RISTRI 4 (2): 145-156.

Gamal, H. R. 2005. Role of arbuscular mycorrhizal fungi in phytoremediation of soil rhizosfer spiked with poly aromatic hydrocarbons. Mycobiol. 33 (1): 4150.

Hanafiah, A. S., T. Sabrina dan H. Guchi. 2009. Biologi dan Ekologi Tanah. Fakultas Pertanian USU. Medan.

Hodiah. 2008. Hasil Jagung yang Diinokulasi Cendawan Mikoriza Arbuskula dan Diberi Fraksi Humat Jeram Padi Pada Tanah Ultisol. J. Agrivigor. 7(2):141148.

Kilham, K. 1994. Soil Ecology. Cambridge University Press.

Neliyati, 2010. Pertumbuhan Batang Bawah Bibit Karet (Hevea brassiliensis Muell. Arg.) dengan Pemberian Mikoriza arbuskular Pada Beberapa 
Kondisi Air di Polibeg. Wubet,T., I. Kottke, D. Teketay, F. Agronomi14(2):34-41. Oberwinkler. 2003. Mycorrhizal

Sinwin, R.M., Mulyati dan Lolita, E.S. 2007. Status Of Indigenous Trees In Dry Peranan Kascing dan Inokulasi Jamur Afromontane Forest Of Ethiopia. Mikoriza terhadap Serapan Hara Ethiopian Agricultural Research. Tanaman Jagung. Jurnal Ilmu Tanah. Forest Ecology And Management Faperta. Universitas Lampung. 179: $387-399$

Lampung.

Wood, M. 1995. Environmental Soil

Biology(2nd Ed.). Chapman \& Hall, Cambridge. 